\title{
Performance of Narmada Nidhi and Local Non Descript Birds Reared in Backyard Farming System for Empowering Women
}

\author{
Deepali Bajpai*, Anil Shinde, Sanjeev Verma and V. K. Verma \\ Directorate of Extension Services, Krishi Vigyan Kendra, Betul \\ Jawaharlal Nehru Krishi Vishwa Vidyalaya Jabalpur(MP)-482004, India \\ *Corresponding author
}

\begin{tabular}{|l|}
\hline Ke y w o r d s \\
$\begin{array}{l}\text { Narmada Nidhi, } \\
\text { Backyard poultry, } \\
\text { Women } \\
\text { empowerment, Egg, }\end{array}$ \\
\hline Article Info \\
\hline $\begin{array}{l}\text { Accepted: } \\
\text { 15 August } 2019 \\
\text { Available Online: } \\
\text { 10 September } 2019\end{array}$
\end{tabular}

\section{A B S T R A C T}

The present study was conducted in four villages of Kesla and Hoshangabad blocks of Hoshangabad District. For household income and food \& nutritional security through women empowerment and to find better performance among the narmada nidhi and local non descript (ND) breed, 25 female and 5 male birds of each breed are distributed to 10 women's of each 4 village in these 2 blocks for backyard rearing. From the experiment, it was concluded that body weight was significantly higher in Narmada nidhi birds as compare to ND birds, similarly egg production was also significantly higher in the Narmada nidhi, birds but age at $1^{\text {st }}$ laying and mortality rate were on the lower side in Narmada nidhi than ND birds though found non-significant among each other. The egg selling rate was same for both the breeds. The study revealed that, Narmada Nidhi as Backyard poultry is play an important role to empower women socially and economically, as a source of income generation, employment opportunities, along with production of valuable foods that reduces household malnutrition

\section{Introduction}

As a nation, India is committed to the empowerment of women. Though women is regarded as 'the unsung heroine who works from dawn to dusk' yet it is unfortunate that even the ignorant and worthless men had been enjoying superiority over women, which they do not deserve and ought not to have according to Gowathami A.S., 2016. Women empowerment is an active, multidimensional process which enables women to realize their full potential and power in all spheres of life as per Renganathan, 2004, Yadav J.S. et al., 2017. It has been observed that, in general rural women contribute more than the men folk in animal husbandry activities as invisible workers, Begam, 1994 and Rehman, 1995. Women are recognized as key players in Backyard poultry production systems and successful engagement with this sector should incorporate gender-sensitive approaches. 
De Bruyn et al., 2015 has been shown that agricultural interventions which target women are more likely to lead to positive nutritional outcomes.

Birds native to our country are very colorful, easy to manage as backyard flocks and are disease resistant. Their meat as well as eggs is in good demand and also fetch a good price. Backyard system of poultry farming is an important enterprise and fundamental part of mixed farming in most of the villages of Hoshangabad, District of Madhya Pradesh, which is based on non-descript and local varieties of poultry stock. The native chicken varieties adopted in the free range backyard conditions in rural areas have low productivity and their contribution to the total egg output is almost static for the last few decades. Therefore, the consumption of eggs in rural areas is far below the national average across the country. Increasing the genetic potential of the local chicken varieties greatly helps in increasing the availability of poultry products in such areas as well as it will create a source of income too. Thus, there is a need to take up the scientific backyard poultry farming programme, to meet the requirements of rural consumers while constituting a source of subsistence income as a subsidiary occupation. Thus In view of the above, the present study was undertaken to assess the empowerment of rural women through the integration of Narmada Nidhi chickens in rural areas.

\section{Materials and Methods}

A day old Twenty five female and five male chicks of each improved dual purpose coloured Narmada nidhi and local non descript (ND) birds were randomly distributed to 10 women's of each 4 villages of Kesla and Hoshangabad blocks of Hoshangabad District (Total 1200 chicks) for rearing in backyard system of farming in village situation. The experiment was conducted at farmers' level under the operational area villages of KVK, Hoshangabad (M.P.). The birds were vaccinated against Newcastle disease (F1 strain at $7^{\text {th }}$ day; R2B Strain at $21^{\text {st }}$ day ) and against Infectious Bursal disease at 14th day along with vaccine for fowl pox at 60th days.

The deworming was done at regular interval to overcome the worm infestation. The data for body weight, mortality and egg production were recorded weekly. The data obtained during experiment were statistically analyzed, following the procedure described by Snedecor and Cochran 1994.

\section{Results and Discussion}

The average weekly body weight and gain in body weight of dual purpose coloured birds (Narmada nidhi) and local non descript birds are shown in Table 1 from 1 to $12^{\text {th }}$ week of age.

The data shows that the body weight was higher from 1 to $7^{\text {th }}$ week in dual purpose coloured bird as compared to local non descript birds though found Non-significant, however after $7^{\text {th }}$ week till $12^{\text {th }}$ week the body weight was found significantly higher in dual purpose coloured birds (Narmada nidhi). The present findings are found similar with earlier report of Sharma et al., 2016 in which they compared the Dual Purpose Coloured Bird with Kadaknath and Krishna $\mathbf{J}$ breeds and reported non significant changes in weekly body weight gain from 1 st to 7 th week among the three breeds.

The finding was not found similar with Singh et al.,2017 who reported gain in body weight was statistically significant from $1^{\text {st }}$ to $11^{\text {th }}$ week in dual purpose coloured bird as compared to local non descript birds, however in $12^{\text {th }}$ week the gain in body weight was found non significant between the two types of bird. 
Table.1 Weekly Body weight gain of Dual purpose colour bird

\begin{tabular}{|c|c|c|c|c|}
\hline \multirow{2}{*}{$\begin{array}{c}\text { Age } \\
\text { (Weeks) }\end{array}$} & \multicolumn{2}{|c|}{$\begin{array}{c}\text { Dual purpose colour bird } \\
\text { (Narmada Nidhi) }\end{array}$} & \multicolumn{2}{|c|}{ Local breed (ND) } \\
\cline { 2 - 5 } & $\begin{array}{c}\text { Body weight } \\
\text { Gain (g) }\end{array}$ & Body weight(g) & $\begin{array}{c}\text { Body weight } \\
\text { Gain (g) }\end{array}$ & Body weight(g) \\
\hline $\mathbf{0 ~ d a y ~}$ & - & $39.1 \pm 0.54$ & - & $38.2 \pm 0.07$ \\
\hline $\mathbf{1}$ & 33.7 & $72.8 \pm 0.35$ & 30.3 & $68.5 \pm 0.12$ \\
\hline $\mathbf{2}$ & 40.2 & $113.0 \pm 0.32$ & 37.5 & $106 \pm 0.43$ \\
\hline $\mathbf{3}$ & 50.5 & $163.5 \pm 0.21$ & 42.3 & $148.3 \pm 0.33$ \\
\hline $\mathbf{4}$ & 57.8 & $221.3 \pm 0.43$ & 51.3 & $199.6 \pm 0.23$ \\
\hline $\mathbf{5}$ & 72.1 & $293.34 \pm 0.22$ & 62.1 & $261.7 \pm 0.78$ \\
\hline $\mathbf{6}$ & 85.6 & $379.20 \pm 0.54$ & 71.02 & $332.72 \pm 0.88$ \\
\hline $\mathbf{7}$ & 112.3 & $491.33 \pm 0.35$ & 95.7 & $428.42 \pm 0.14$ \\
\hline $\mathbf{8}$ & 127.8 & $619.12^{\mathrm{a}} \pm 0.27$ & 110.4 & $538.82^{\mathrm{b}} \pm 0.55$ \\
\hline $\mathbf{9}$ & 168.3 & $787.45^{\mathrm{a}} \pm 0.67$ & 133.2 & $672.02^{\mathrm{b}} \pm 0.19$ \\
\hline $\mathbf{1 0}$ & 182.4 & $969.18^{\mathrm{a}} \pm 0.51$ & 159.7 & $831.72^{\mathrm{b}} \pm 0.46$ \\
\hline $\mathbf{1 1}$ & 208.4 & $1178.23^{\mathrm{a}} \pm 0.49$ & 180.9 & $1012.62^{\mathrm{b}} \pm 0.67$ \\
\hline $\mathbf{1 2}$ & $\mathbf{2 1 7 . 7}$ & $\mathbf{1 3 9 5 . 9 1}^{\mathbf{a}} \pm \mathbf{0 . 9 1}$ & $\mathbf{1 8 2 . 2}$ & $\mathbf{1 1 9 4 . 8 2}^{\mathbf{b}} \pm \mathbf{0 . 5 9}$ \\
\hline
\end{tabular}

Table.2 Vaccination Schedule of the birds

\begin{tabular}{|l|l|l|l|}
\hline Age(days) & Vaccine used & Dose & Administration route \\
\hline $\mathbf{1}$ & Marek's & $0.2 \mathrm{ml}$ & $\mathrm{S} / \mathrm{C}$ at neck \\
\hline $\mathbf{6 - 7}$ & F1 strain $(\mathbf{R D})$ & $1-2 \mathrm{drops}$ & $\mathrm{I} / \mathrm{O}$ \\
\hline $\mathbf{1 2 - 1 4}$ & Gamboro & $1-2 \mathrm{drops}$ & $\mathrm{I} / \mathrm{O}$ \\
\hline $\mathbf{2 1 - 2 2}$ & R2B & - & $\mathrm{S} / \mathrm{C}$ or $\mathrm{I} / \mathrm{M}$ \\
\hline $\mathbf{6 0 - 7 0}$ & Fowl Pox & $0.2 \mathrm{ml}$ & $\mathrm{I} / \mathrm{M}$ \\
\hline
\end{tabular}

Table.3 Production performance of Narmada Nidhi and Local colored birds

\begin{tabular}{|c|c|c|}
\hline Particular & Narmada Nidhi & Local Breed \\
\hline $\begin{array}{c}\text { Egg production (Up to } \\
\mathbf{1 2} \text { months of age) }\end{array}$ & $110^{\text {a }} \pm 1.32$ & $\mathbf{7 0}^{\mathbf{b}} \pm \mathbf{2 . 0 1}$ \\
\hline Age at Ist Laying (wk.) & $22 \pm 0.58$ & $\mathbf{2 4 \pm 0 . 3 3}$ \\
\hline Mortality (\%) & $\mathbf{1 3 . 3 4} \pm \mathbf{0 . 2 8}$ & $\mathbf{2 6 . 6 6} \pm \mathbf{0 . 7 6}$ \\
\hline
\end{tabular}


Table.4 Income/Output

\begin{tabular}{|c|c|c|c|c|}
\hline \multirow[t]{2}{*}{ Particulars } & \multicolumn{2}{|c|}{ Narmada Nidhi } & \multicolumn{2}{|c|}{ Local Breed } \\
\hline & Rate & Cost (Rs.) & & \\
\hline \multicolumn{5}{|l|}{ (A) Expenditure } \\
\hline $\begin{array}{l}\text { i. Cost of pullet and } \\
\text { cockerel ( } 8 \text { wks.) }\end{array}$ & $\begin{array}{l}\text { Rs. } 80 / \text { - per } \\
\text { chick } x 30\end{array}$ & 2,400 & $\begin{array}{l}\text { Rs. } 80 /- \text { per } \\
\text { chick } \times 30\end{array}$ & 2,400 \\
\hline ii. Cost of medicines & $\begin{array}{c}\text { Rs. 5/- per chick } \\
\text { x } 30\end{array}$ & 150 & $\begin{array}{l}\text { Rs. } 5 / \text { - per } \\
\text { chick x } 30\end{array}$ & 150 \\
\hline iii. Cost of feed & $\begin{array}{l}\text { Rs. } 5 / \text { - per day } x \\
12 \text { months }\end{array}$ & 1800 & $\begin{array}{l}\text { Rs. } 5 / \text { - per day } \\
\text { x } 12 \text { months }\end{array}$ & 1800 \\
\hline iv. Miscellaneous cost & $\begin{array}{l}\text { Rs. 2/- per chick } \\
\text { x } 30\end{array}$ & 60 & $\begin{array}{l}\text { Rs. } 2 / \text { - per } \\
\text { chick x } 30\end{array}$ & 60 \\
\hline Total expenditure & & 4,410 & & 4,410 \\
\hline \multicolumn{5}{|l|}{ (B) Return } \\
\hline i. Sale of cocks & $\begin{array}{l}\text { Rs. } 350 / \text { - per } \\
\text { cock x } 2\end{array}$ & 700 & $\begin{array}{l}\text { Rs. } 350 / \text { - per } \\
\text { cock x } 2\end{array}$ & 700 \\
\hline $\begin{array}{l}\text { ii. Present value of } \\
\text { cocks }\end{array}$ & $\begin{array}{l}2.4 \mathrm{~kg} . \times \mathrm{Rs} . \\
250 /-\mathrm{x} 3\end{array}$ & 1,800 & $\begin{array}{l}2.0 \mathrm{~kg} . \times \mathrm{Rs} . \\
250 /-\mathrm{x} 3\end{array}$ & 1,500 \\
\hline $\begin{array}{l}\text { iii. Consumed or Sale of } \\
\text { eggs (Upto } 12 \text { months) }\end{array}$ & $\begin{array}{l}110 \text { Nos. } x 21 \\
\text { hens x Rs. } 7 /-\end{array}$ & 16,170 & $\begin{array}{l}70 \text { Nos. x } 17 \\
\text { hens x Rs. 7/- }\end{array}$ & 8,330 \\
\hline iv. Present value of hens & $\begin{array}{l}1.75 \text { kg. x } 21 \\
\text { x Rs. } 200\end{array}$ & 7,350 & $\begin{array}{l}1.55 \text { kg. x } 17 \\
\text { x Rs. } 200\end{array}$ & 5,270 \\
\hline Gross return & & 26,020 & & 15,800 \\
\hline Total profit (B-A) & & 21,610 & & 11,390 \\
\hline Profit/member & & 21,610 & & 11,390 \\
\hline B:C. Ratio & & 4.90:1 & & 2.58:1 \\
\hline
\end{tabular}

The production performance (egg production, age at first laying, and mortality) of dual purpose colored birds and non descript birds are shown in Table 3. From the table it is clear that egg production was significantly higher $(\mathrm{P}>0.05)$ in Dual purpose coloured birds as compare to local non descript birds. The present findings are in line with earlier report of Sharma et al., 2016. We experienced same case as like singh et al., 2017, where they observed that the availability of scavenging area mainly attributed to the higher egg production.

The eggs were laid between 15-20 days interval. The age at Ist Laying, was low in Narmada Nidhi as compared to non descript breed indicating superiority of dual purpose coloured bird over the non-descript local bird but was non significant. Our results are found similar with Sharma et al., (2016) who have reported age at first laying to about $21.15 \pm 0.36$ weeks in Dual Purpose coloured bird. The mortality rate was also found higher in local ND birds as compare to Dual Purpose coloured bird. The high mortality in local cross birds was due to low resistant power of diseases. The Income/Output was found higher from the Narmada Nidhi with B:C ratio of 4.90 as compare to local Non descript breed (2.58).

From the above experiment, it may be concluded that Dual purpose coloured bird 
(Narmada Nidhi) has high body weight gain, higher egg production as compared to local non descript breed. As the Income/Output was found higher from the Narmada Nidhi as compare to local Non descript breed, Narmada Nidhi as Backyard poultry can play an important role to empower women socially and economically, as a source of income generation, employment opportunities, along with production of valuable foods that reduces household malnutrition and thatswhy can be popularize in rural areas for backyard rearing.

\section{References}

Begam, Y. 1994. Suitability of animal husbandry practices and its adoption amongst farm women. M.Sc. thesis, IVRI, Izatnagar.

De Bruyn, J., Wong, J., Bagnol, B., Pengelly, B. and Alders, R. 2015. Family poultry production and food and nutrition security. CAB Reviews 10(13):1-9.

Gowathami

A.S.

(2016), http://cttebba.blogspot.com/2016/03/astudy-on-women-self-help-groupin.html

Rehman, S. (1995). A study of social and economic aspects of livestock owning
Gujjar and Bakarwal tribe of Jammu and Kashmir. Ph.D. Thesis, Division of Extension Education, IVRI, Izatnagar.

Renganathan, R., 2004. Women's empowerment through development programmes. Kisan World, 31: 13-14.

Sharma P. and Sahu S. (2016). Performance of Kadaknath, Krishna-J and improved dual purpose coloured birds under backyard system of rearing. Indian Veterinary Journal, 93 (06): 35 - 37.

Singh P.P., Chauhan S.V.S. and Singh Y.P. (2017). Evaluation of Performance of Improved Dual Purpose Coloured Birds under Backyard System of Rearing at Morena district of Madhya Pradesh. Indian Reseach Journal of Extension Education 17 (3).

Snedecor, G.W. and Cochran, W.G. (1994). Statistical methods, 8th edu. Iowa State University Press, Ames, Iowa.

Yadav J. S., Singh R., Mandal M K. Integration of Innovative Technology 'Narmada Nidhi' in Backyard Poultry Farming for Empowering Tribal Women Self-Help Groups. Dairy and Vet Sci J. 2017; 4(3): 555637. DOI: 10.19080/JDVS.2017.04.555637.

\section{How to cite this article:}

Deepali Bajpai, Anil Shinde, Sanjeev Verma and Verma, V. K. 2019. Performance of Narmada Nidhi and Local Non Descript Birds Reared in Backyard Farming System for Empowering Women. Int.J.Curr.Microbiol.App.Sci. 8(09): 1416-1420. doi: https://doi.org/10.20546/ijcmas.2019.809.162 